\title{
Problems, Prospects and the Role of Micro and Small Enterprises in Economy the Case of Western Hararghe
}

\author{
${ }^{1}$ Emebet Abera, ${ }^{2}$ Atinafu Yadesa, ${ }^{2}$ Tale Gedefa \\ ${ }^{1}$ Principal Investigator: \\ ${ }^{2}$ Co-Investigator: \\ Oda Bultum University
}

\begin{abstract}
The present study aimed to investigate the Problems, Prospects and the role of Micro and Small Enterprises in economy the case of Western Hararghe. The greatest challenges of micro enterprises, opportunities of micro enterprises, the roles of micro enterprises in employment generation, the roles of micro enterprises in entrepreneurial development had been identified. The sample of the study consists of all the micro and small enterprises and micro enterprise offices in Western Hararghe. Stratified random sampling was used to get information from different sizes of the SMEs.The data were collected from 197 micro and small enterprises and micro enterprise offices in Western Hararghe. The data were gathered using questionnaire and interview. The data obtained were analysed using both quantitative and qualitative techniques. Quantitative data obtained were analysed using descriptive statistics and independent sample t-test. The qualitative data were analysed using narration. Comparison of the Fairness of tax based on establishment time using t-test show that that there was no significant difference between MSEs based on establishment time and result of comparison of MSEs on Profitability in relation to establishment time show there was no significant difference among MSEs regarding profitability.
\end{abstract}

\subsection{Background of the study}

\section{INTRODUCTION}

There is no doubt that SMEs play a significant role in the creation employment opportunity to the population. Reviews of studies in the area confirm that the contributions of SMEs in this regard have long been recognized all over the globe (cf., Liedholm, 2001, ILO, 2003a, Vandenberg, 2004, Mazumdar, 2004, Haftu, et al, 2009). Beck and Demirguc-Kunt (2006), for example, report that small enterprises (along with medium) are major derivers of both employment and economic growth contributing to more than $50 \%$ to GDP and $60 \%$ to employment in developed economies, These type of enterprises, however, constitute less than 30\% of employment and 17\% of GDP in developing countries. Indeed, a study conducted in Africa by the ILO finds that only $20 \%$ of the total populations of working age group in many African countries were reported to have been working in the small enterprise sector (ILO, 2003a). Micro-econometric studies using enterprise level data from SMEs sector has indicated that many of these enterprises have low levels of productivity, produces low quality products and grows only when they were young (e.g., Mead sndLieadholm, 1998; Tybout, 2000).

Similarly, in Ethiopia's situation, as result of research conducted in previous time, most of SMEs have been confronted by many problems like lack of access to finance, working premises (Endalkachew, 2008), lack of market for their products ( Eshetu and Mammo, 2009), lack of skills and managerial expertise, infrastructure, information and appropriate technology. These problems result in failure of businesses and have the effect of preventing their expansion almost from the beginning of their operations. (Gebrehiwot and Walday, 2006, Netsanate, 2009). Most of the researches done by above researchers were focused on rural micro and small enterprises and some of them are national wide researches. Thus, this paper will work to identify Problems, Prospects and the role of Micro and Small Enterprises in economy in the case of Western Hararghe.

\subsection{Statement of the problem}

Poor countries, like Ethiopia, at this time are highly attached with different problems like poverty, unemployment, backward culture, famine, illiteracy, high population growth rate etc. According to Federal Urban Development Package of Ethiopia 2005, "In Ethiopia, the number of people who can work continues to grow more rapidly than the ability of the economy to provide new employment opportunities. Unemployment, particularly urban unemployment, is one of the critical problems in the country. The rate of urban unemployment in the country was 26.4 percent in medium towns and 40 percent in large urban towns in 2005"

Western Hararghe in relation to Ethiopia's other towns is highly affected by draught due to shortage of land and rain. This and other factors affected western Hararghe to have many unemployed, less income or poor people.

The micro and small enterprise development strategy has started implementation recently in Ethiopia to reduce urban unemployment, poverty and bring economic development. Due to this, promoting SMEs has been taken as a tool in Western Hararghe, like other cities of Ethiopia. As the result of this, many SMEs are created in the past years. Those SMEs flourished are individually owned and cooperatives enterprises. The questions are whether these enterprises contribute to employment generation and its sustainability? If SMEs contribute to income creation for those individuals engaged in SMEs? What are the prospects and challenges of SMEs? 


\subsection{Objectives of the study}

1.3.1. General objective:

The general objective of the study was to assess Problems, Prospects and the role of Micro and Small Enterprises in economy in the case of Western Hararghe.

\subsubsection{Specific objectives}

The specific objectives of the study were:

1. To assess greatest challenges of micro enterprises.

2. To assess opportunities of micro enterprises in Western Hararghe.

3. To assess the roles of micro enterprises in employment generation.

4. To assess the roles of micro enterprises in entrepreneurial development.

5. To make recommendations on intervention measures that can help in improving the performance of micro enterprises.

\subsection{Scope of the study}

The study covered manufacturing industry, service and construction sectors of SMEs in Western Hararghe. In this research the samples were taken from SMEs which were registered by trade and industry office.

\subsection{Significance of the study}

There are many SMEs in Western Hararghe. Their potential to create employment and to generate income makes them crucial economic instrument. Hence, the result of the research provided relevant information to policy makers and local development planners working on the development of conducive environment for SMEs. Furthermore, the study provides additional information about the role of SMEs in employment creation in Western Hararghe for interested researchers, prospective entrepreneurs, and business consulting firms.

\subsection{Operational definition of the variable}

MSEs:

Micro and small enterprises

MFI :

Micro finance institution

\section{REVIEW OF RELATED LITERATURE}

The history of small business has been one of the most controversial stories in economic development in the world. It is not known when MSEs start. The role of small business in an economy has frequently been undermined and misinterpreted this is because that many governments emphasize on the attraction and promotion of large enterprises by thinking that most of the economic development or income comes from large industries.

\subsection{Definition and classification of MSEs}

What is stated or identified as micro and small enterprises in many industrialized countries may differ in other developing countries. In developed countries micro enterprises can be labeled as small or medium in developing countries. This is because the amount of capital invested and the number of people employed in operating and implementing MSEs and the level of technology vary from one country to another. In some countries MSEs labeled based in the number of employees and others on capital invested.

Most definitions of MSEs depend up on the policy makers (financiers, labor officers, traders and service personnel). The common criteria that are used by different countries are 1. Number of employees 2. Asset employed 3. Sales turn over or 4. Combination of the above three factors. The Central Statistical Authority (2002) of Ethiopia, defined MSEs ,'as household type establishment /activity/, which are mainly engaged in marketed production, are not registered companies or co-operatives, have no full written book of accounts, have less than 10 persons engaged in the activities and have no license."

To determine the size of enterprise, Hailay (2003) gives the following category of industry and criteria.

Investment paid up capital not exceeding $\mathrm{Br} 20,000$ Investment paid up capital $\mathrm{Br}$ 20,000 50,000 France MSE <500 employees USA Very small enterprise 10-499 employees Indonesia Micro enterprise Small enterprise Medium enterprise $<20$ employees 20-99 employees 100-499 employees Ghana Micro enterprise Small enterprise Medium enterprise 1-4 employees 5-29 employees 30-140 employees Source: hailay 2003 Micro and small enterprises are defined in several countries within their different purposes and intention. Thus, definitions depend on the government policies. There are different MSEs, which have different technological advancement or know how, the nature of the raw materials use and the market they have for their product. These different classes of enterprises seen in the above are different with their developmental advantages and with respect to their impact of policy and policy change. Thus it makes problematic to speak or define MSEs in universally accepted 
way (Drik 1994, cited in Ephrem 2005). However the yardsticks more or less applied by most countries singly or in combination are the following

- capital investment in plant and machinery

- number of workers employed

- $\quad$ volume of production or turn over business (Hewaliyan, 2002)

According to Jean-Luc Camilleri (2005) In Africa, MSEs will be divided in three levels. The enterprises whose capital is less than Euro 100- MSEs that are small and survival business in particular engaged in the field of trade. Their potential accumulation or growth is almost zero.

The enterprises whose capital is between Euro 100 and Euro 700- These emerging enterprises sometimes have premises and sufficient technical knowledge like traditional blacksmiths and carpenter. Their technologies are simple, their tools basic and their needs mostly in working capital but also in equipment (Jean-Luc Camilleri).

The enterprises whose capital is between Euro 700 and Euro 10,000- In this area, activities are not seasonal but permanent enterprises such as welders operate with fixed premises and more sophisticated technologies which require relatively important investments. The dynamic micro enterprises with high potential growth can be assimilated to small enterprises (Jean-Luc Camilleri)

\subsection{Common Characteristic of MSEs}

There are assumptions that are common characteristics of MSEs. These common characteristics are; they have few employees, give low income, not experience much growth and do not produce for markets outside their local environment (Eversole, 2003).

\subsection{Employment Generation}

Available evidence suggests that micro enterprise do not show growth in terms of number of people employed (Mead,D,C and Liedlholm,C, 2000). While small firms experience both high job creation and destruction rates, it appears that job destruction during recession is lower in small enterprise than in large enterprises perhaps due to greater wage flexibility in small firms (Snodgrass \& Biggs 1998). In contrast, large firms offer better in terms of wages, fringe benefits, good working conditions, opportunities for skill enhancement and job security (Snodgrass \& Biggs 1998). According to the study made by liedlholm (2002), the closures rate for MSEs of developing countries in Africa and Asia is occurred in the early years of firm's existence. In Kenya, Botswana, Swaziland, and Zimbabwe, over 50 percent of the small firms get closed within three years of start-up. Ibid page 22 added that "Since small firms have higher gross job creation and destruction rates than large enterprises, small firms may offer less job security than large firms. In the US for both new and already existing jobs, Jobs durability increases with firm size'”.

\subsection{Location and Survival Rate of MSEs}

Location can play a central role in determining MSEs survival. MSEs located in urban or commercial areas are more likely to survive than their counter in rural areas. Those that operate in commercial districts or on road sides typically show greater growth rates than those that are based on their home, although it can vary at the country level (Liedlholm, 2002).

\section{3. . Gender and MSEs}

According to op.cit based on the study of the nine countries; in five of these countries women outnumber men as owners and operators of MSEs. Those small firms tend to be concentrated in relatively specific activities like beer brewing, knitting, dress making, crocheting, cane work and retail trading. Ibid page 5 added that MSEs headed by women are more likely to be based out of their homes. Home based MSEs tend to be hidden to markets and because most homes are not on streets that people pass.

\subsection{Labor Distribution in MSEs and Large Enterprises}

Small firm expansion boosts employment more than large firm growth, because small firms are labor intensive, coinciding with the factor market structure of most developing countries. Many analysts argue that within industries, for a given scale of production, small firms are more labor intensive than large firms. However there are some evidences suggests that enterprise scale is an unreliable guide to labor intensity because many small firms are more capital intensive than large firms in the same industry. Labor intensity exhibits more variation across industries than among firm size groups within industries (MSE DEGPR, 2006). According to the study made by Sondgrass \& Biggs (1998) depicted that "The fact that small firms employ a large share of the labor force in developing countries may be a more reflection of the product composition of production in those countries than inherent labor intensity of small firms',

\subsection{Income}

While there are many exceptions to the basic pattern, the evidence suggests that larger employers offer better jobs in terms of wages, fringe benefits, working conditions and opportunities for skills enhancements as well as job security. In low-income countries, small enterprises have much lower productivity levels than larger firms which lead to lower wages and non-wage benefits. There is some evidence that this divergence in labor productivity and wage rates between small and large firm's narrows as countries become more developed in terms of industrialization (Snodgrass and Biggs 1998). 


\section{6. . Efficiency and Innovation in MSEs}

Efficiency and innovation is one of the determinants in MSEs survival. Sondgrass and Biggs (1998) stated that;

"There has been a substantial difference detected in economic efficiency among enterprise of varying sizes. It is often argue that small firms are more innovative, particularly when they follow "niche strategies" using high product quality flexibility and responsiveness to customer needs as a means of competing with large scale mass producers".

Measures of enterprise efficiency vary greatly both within and across industries. Those that varies are labor productivities or total factor productivities. Among the total factor productivities; financial market, imperfections such as information asymmetries, transaction costs and contract enforcement costs are particularly affecting the poor who lack collateral and cre dit histories not to work efficiently (Beck, et.al, 2004 cited in MSE Degpr, 2006). Joseph Schumber (1995), a remarkable analyst and advocate of capitalism, asserted that the hall mark of capitalism is innovation. The only survivors are those who constantly innovate and develop new products and process to replace the old ones (Brown and Latour, 2004 cited in Kelly D. Edmison 2004).

\section{7. . Market Linkage}

In a study made by MSE DGPR (2006), it is described that "Market linkages amongst small firms are quite limited. The majority of small firms sell directly to final consumers although some use contracting and clustering". The study of Millhold (2002) suggests that those MSEs that sell to traders and manufacturing firms are more likely to grow than other MSEs sells to final consumers and in view of (Small Enterprise Assistance Funds, 2004) that "Smaller business may import fewer intermediate goods. A greater amount of products are purchased from labor intensive MSEs which may produce a large local multiplier effects". This in turn can lead to increased opportunities for locally sustainable growth and employment.

\section{3. . The quality of employment in MSEs}

Employment growth in small enterprises does not necessarily reflect a successful development strategy. It is also important to consider the quality of employment, which can be broadly defined as the work-related factors that have an impact on the economic, social and psychological wellbeing as well as on the health of the employed persons (Reinecke,G. 2000).

On average, jobs in small enterprises are less productive, less remunerated, less secure and less unionized than jobs in larger enterprises, even after controlling for observable workers characteristics, such as education, sex and age (Reinecke, G. 2000). For instance, the study by Soderbom (2001) estimates that in Ghana"s manufacturing sector, a 10 percent rise in firm size is statistically associated with a 1.6 percent rise in earnings. For these reasons, many people concerned with employment quality and industrial relations view the growing emphasis on small enterprise employment as a threat rather than an opportunity. Moreover, as mentioned above, some people find work in small enterprises simply because they have no alternative. For these persons, it is a kind of survival strategy that is adopted despite low and possibly declining returns until something better comes along. As such, it is a reflection of economic failure rather than success. These enterprises can be very important in helping a large number of very poor people become a little less poor but they can generally not provide employment of high quality (Op.cit, 2000).

Most studies considering employment quality in small enterprises largely focus on income levels (or profits for the enterprise owner in the case of very small enterprises). Obviously, income is indeed a crucial dimension of employment quality, especially in countries where many workers" incomes are insufficient to move the household they live in beyond the poverty line. However, other dimensions of employment quality, such as occupational health issues, job security and the degree of social protection are also crucial for the well-being of the employed persons in small enterprises and their household members (Op.cit2000). Employment quality is thus a multidimensional concept (Ibid, page 97). In many developing countries, an improvement in the labour market performance may not directly be observed via decreasing rates of open unemployment or employment creation. Many persons whose employment situation improves may move from under-employment or bad quality employment to full employment or better quality employment.

\subsection{MSE's Contribution to Employment Generation and Income Creation. 2.8. International Experience}

Government of less developed countries have been supporting for micro and small enterprises through various programs such as credit schemes, entrepreneurship training, technology support etc (Zaid and Torben, 2003). According to Todaro (2000) the informal sector is a major provider of urban jobs in many Asian countries. Among individual countries for which statistics available, the figure reaches 50 percenet in India, 45 percent in Indonesia, 35 percent in Malaysia and 60 percent in Pakistan. In the case of Latin American countries 61 percent in Bolivia, 55 percent in Argentina, 56 percent in Brazil, and 69 percent in Paraguay. Besides, ILO (1998) survey report of 17 African countries found that the informal sector contributes on average 20 percent of GDP and 61percent of the sub-Saharan labour force employment. For instance, in the years between 1980 and 1985 the employment share of MSEs for Kenya and Ghana was around 40 percent and 80 percent respectively, out of the total urban employment. 
According to Staley and Morse (1992), 81 percent of the manufacturing establishments in the United States in 1980 had small enterprises with less than 100 employees. These establishments employed 25 percent of all manufacturing employees and produce 23 percent of the total value added by manufacturers. The relative importance of small enterprises in West Germany and United Kingdom was also greater, 27 percent and 26 percent of all manufacturing employees respectively. The percentage of small enterprises employment are even higher like in New Zealand 62 percent, Argentina 52 percent and Japan 56 percent (Staley and Morse,1992) Hence, this shows that micro and small enterprises are contributing significantly even in developed countries.

In 2000 China had more than 20.85 million small-scale enterprises, with 128.2 million employees and generating 2,720 billion dollar in added value, and 9.14 percent increase every year of the small- scale enterprises (Daniels, L. and Mead, D.C. 1998).

In Kenya, according to the National Baseline survey of 1999, there were about 1.3 million MSEs, employing 2-4 million Kenyans, equivalent to 15 percent of the total employment and contributing 18 percent of the GDP of the country. Moreover, the MSEs sector in Kenya is very dynamic with rapid investment rates and enterprise growth (Kimuye, 1999). According to UNCTAD (2005), the income contribution of the micro and small enterprises sector in Tanzania was about 20-30 percent of the GDP, and they consist of more than 1 million enterprises engaging three-four million persons, that are about 20-30 percent of the labour force of the country.

In Burkina Faso, based on the 1990 survey on MSEs, there were 90,000 established micro enterprises. Between 1985 and 1982, the sector is estimated to have contributed 30 percent of the GNP which exceeded agriculture (20-45 percent) and the modern secondary sector (23-86 percent) in the same period. Moreover, the MSEs sector employs 77 percent of the nonagricultural population and 8.6 percent of the total active population of Burkina Faso (UNCTAD, 2005).

According to Wick ware 1998; cited in Loop, 2000), MSEs have a significant contribution in creating employment opportunities for the poor in urban areas. Accordingly, he estimates the percentage of people engage in such sectors in some sub-Saharan cities during the 1900s as; Accra 70 percent; Addis Ababa 61 percent; Dare Salaam 56 percent; Kampala 46 percent; and Harare 17 percent. Hence, MSEs have important employment share in the economy of those cities.

\subsection{Ethiopian Experience}

Micro and small enterprises (MSEs) are a special focus of the government, given that they comprise the largest share of total enterprises and employment in the non-agricultural sectors. In recognition of the important role MSEs have to play in creating income and employment opportunities and reducing poverty, the government drafted its first micro and small enterprise development strategy in 1997. According to the Central Statistical Authority (CSA) survey, there are almost 570,000 MSEs in Ethiopia, 99.4 percent of which are micro-enterprises with fewer than ten employees, accounting for 88.2 percent of private sector employment. The microenterprises are very small. On average, they employ one and a half workers (this includes the owner and perhaps one occasional helper), and earn an annual operating surplus of 1,300 birr. Sole proprietors operated 82 percent of urban enterprises. Of the total employment in these urban micro-enterprises, family members accounted for 60 percent. Beyond family members, apprentices constituted a large proportion of the remaining MSE work force (CSA, 2003).

The average micro-enterprise has a capital of 3,528 birr, a yearly production value of 2,300 birr and an annual surplus of 1,300 birr. Although small enterprises significantly more productive and profitable than micro-enterprises, small-scale industries are also very small, with an average of slightly more than three employees, 18,934 birr in annual operating surplus, capital of 38,554 birr, and production value of 68,800 birr. A recent study on MSEs indicated that MSEs in Ethiopia are confronted by many problems. The constraints facing MSEs in most developing economies are similar: unfavourable legal and regulatory environment and, in some cases, discriminatory regulatory practices; lack of access to markets, finance, business information; lack of business premises at affordable rent; low ability to acquire skills and managerial expertise; low access to appropriate technology; and poor access to quality business infrastructure (CSA, 2003).

According to the CSA report, the major obstacles experienced by small-scale manufacturing industries were the irregular and erratic supply of raw materials and a shortage of suitable working premises. The lack of working premises was also found to present difficulties for the informal sector operators, who faced with insufficient capital, were often impeded from the start (Ibid, page 36).

The problem of raw material shortages, lack of working capital and effective marketing practices faced by micro and small manufacturing industries result in the failure of these businesses to expand (Ibid, page 35, 2003). The same problems, when experienced by informal sector operators, have the effect of preventing their expansion almost from the beginning of their operations Ibid, page 35. Results of the Ibid, page 43 survey showed that for about 50 percent of informal sector operators, the first major difficulty when starting their operation was the lack of sufficient initial capital and this problem becomes more critical when the informal sectors operators intended to expand their businesses. 


\section{METHODOLOGY}

The study was undertaken in western Hararghe which is found in Eastern part of Ethiopia. The study included micro and small enterprises in each Wereda including the zonal town Chiro. Thus, the study focused on Problems, Prospects and the role of Micro and Small Enterprises in economy in the case of Western Hararghe.

\subsection{Research design}

The goal of this study was to evaluate Problems, Prospects and the role of Micro and Small Enterprises in economy. It was survey study, one of the descriptive studies. The survey method was selected for this particular study as it was found to be an appropriate technique for collecting vast information and opinions from quite a large number of respondents to find out the existing situation on micro and small enterprises in western Hararghe.

\subsection{Sources of Data}

Primary and secondary data were used in generating valuable and relevant data for the study.

These data was gathered from micro and small enterprises and micro enterprise offices in Western Hararghe. The major sources of the data were thus, micro and small enterprises and micro enterprise offices in Western Hararghe.

Primary source: primary data was collected through field work survey. Information on the status of employment, income and other data was collected from the MSEs owners, employees, and from process owner of Trade, Industry and Transport bureaus in Chiro.

Secondary sources: In this study, secondary data was collected from officially published and unpublished materials, Reports, statistical bulletins, brochures and other materials for necessary information.

\subsection{Population of the Study}

Population of this study were all micro and small enterprises and micro enterprise offices in Western Hararghe. There are 3696 micro enterprises and 197 small enterprises found in western Hararghe.

\subsection{Sampling Technique}

Stratified random sampling was used to get information from different sizes of the SMEs. This technique was preferred because it is used to assist in minimizing bias when dealing with the population. With this technique, the sampling frame can be organized into relatively homogeneous groups before selecting elements for the sample.

In this study to select sample size, a list of the population formally registered SMEs Trade and Industry offices was used. The total population of the study was 3696 micro enterprises and 197 small enterprises. The researcher used the sample size determination formula, which was developed by Yamane (1967:886), to determine the sample size of SMEs for the study. $\mathrm{n}=\mathrm{N} /$ $\left(1+\mathrm{N}(\mathrm{e})^{2}\right.$ Where $\mathrm{n}$ is the sample size, $\mathrm{N}$ is the total SMEs in the selected weredas. After determination of sample size, stratified sampling method was employed.

\subsection{Instruments of Data Collection}

In order to procure data for this study, two data collecting instruments were used. These were:

1. Questionnaire and

2. Interview.

\subsection{1. . Questionnaire}

Questionnaire was used as a major data collecting instrument due to its convenience to collect adequate data from a large number of respondents. To make the data manageable, close ended questionnaire was prepared to collect data from the relevant respondents. The questionnaire was translated to afan Oromo as respondents were users of the stated language.

\subsubsection{Interview}

Data was also collected through interview to crosscheck data obtained through questionnaire.

\subsection{Method of Data Analysis}

After the collection of data through questionnaire, the raw data was classified and tabulated depending on the kind of question to make it easily manageable and understandable. After it was tabulated, the issues were analysed and interpreted based on the kind of question by using different analytical methods. Descriptive statistical tools such as tables, percentages, were used. Mean, maximum, minimum were used to classify the respondents annual income and number of employees per MSEs in to the above mean, below the mean, the minimum and the maximum. Challenges, opportunities, and role in entrepreneurial development were analysed by descriptive statistical tools using SPSS.

\section{RESULTS AND DISCUSSION}

This chapter deals with the presentation and analysis of the data collected from MSE owners and MSE officers. The data was gathered from through MSE owners and MSE officers using questionnaires and interview, respectively. All the data gathered from the questionnaires were organized and analyzed in tabular form and interpreted using frequency, percentage, mean and independent sample t-test. The qualitative information gathered through interviews were narrated and interpreted in qualitative manner. The first part of this chapter deals with characteristics of respondents while the second part deals with the analysis of the data corresponding to each question.

\subsection{Demographic characteristics of the participants}

Overall demographic characteristics of respondents are discussed on the table below. 
4.1.1. Gender and educational background of respondents

Table 4. 1.Trend of Gender and education level of respondents

\begin{tabular}{|c|c|c|c|c|}
\hline & Gender & & & \multirow{3}{*}{$\begin{array}{l}\text { Total } \\
197\end{array}$} \\
\hline & \multicolumn{2}{|l|}{ Male } & \multirow{2}{*}{$\begin{array}{c}\text { Female } \\
82\end{array}$} & \\
\hline Frequency & 115 & & & \\
\hline Percentage & 58.4 & & 41.6 & 100 \\
\hline \multirow[t]{2}{*}{2} & Education level & & & \\
\hline & $\begin{array}{l}\text { Secondary school graduates \& } \\
\text { below }\end{array}$ & TVET \& diploma holders & $1^{\text {st }}$ degree $\&$ above & Total \\
\hline Frequency & 105 & 73 & & 197 \\
\hline Percentage & 53.3 & 37.1 & & 100 \\
\hline
\end{tabular}

As indicated in table 4.1., among the respondents of western Hararghe, $58.4 \%$ were male and $41.6 \%$ were female and among these respondents $53.3 \%$ were secondary school graduates \& below, $37.1 \%$ were TVET graduates \& diploma holders and 9.6were $1^{\text {st }}$ degree and above graduates.

Table 4. 2. Trend of Age and Marital status of respondents

\begin{tabular}{|c|c|c|c|c|c|c|}
\hline 3 & Age & $31-40$ & $41-50$ & $51-60$ & $61 \&$ above & Total \\
\hline Frequency & 146 & 44 & 7 & 0 & 0 & 197 \\
\hline Percentage & 74.1 & 22.3 & 3.6 & 0 & 0 & 100 \\
\hline \multirow[t]{2}{*}{ (1) } & Marital status & & & & & \\
\hline & Unmarried & Married & Divorced & widowed & Total & \\
\hline Frequency & 90 & 104 & 3 & 0 & 197 & \\
\hline Percentage & 45.7 & 52.8 & 1.5 & 0 & 100 & \\
\hline
\end{tabular}

Table 4.2. Above indicates that $74.1 \%$ of the respondents lay in the range of $18-30$ years old, whereas $22.3 \%$ and $3.6 \%$ of them aged in the age group of 31-40 and 41-50 years old respectively. On the other hand, the marital status of these respondents shows that $45.7 \%$ were unmarried, $52.8 \%$ were married and $1.5 \%$ of them are divorced.

\subsection{Response on business profiles}

Kind of enterprise, size and number of members are discussed on the table 4.3.

Table 4. 3. Response on the kind of enterprise, size and number of members

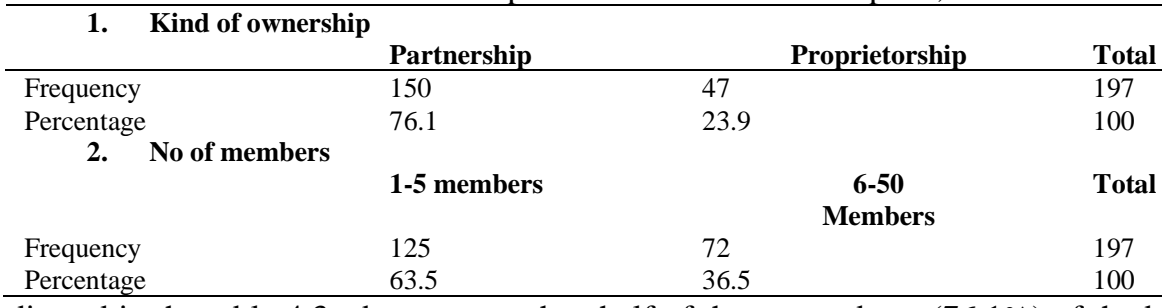

As indicated in the table 4.3. above, more than half of the respondents $(76.1 \%)$ of the businesses were partnership kind and the rest $(23.9 \%)$, were proprietorship kind of business. From these respondents it is shown on the table that $63.5 \%$ were micro enterprises and the rest $36.5 \%$ were small.

\subsubsection{Response on motivation to start business}

Reasons that motivated people to start business has discussed in Table 4.4. below.

Table 4. 4. Reason to start business

\begin{tabular}{lccccc}
\hline 1. & $\begin{array}{c}\text { Factors motivated to start business } \\
\text { Profitability of the } \\
\text { business }\end{array}$ & $\begin{array}{c}\text { Lack of employment } \\
\text { alternatives }\end{array}$ & Good government support & $\begin{array}{c}\text { Total } \\
\text { Prevperious }\end{array}$ \\
\hline Frequency & 28 & 144 & 15 & 10 \\
Percentage & 14.2 & 73.1 & 7.6 & 197 \\
\hline
\end{tabular}

Table 4.4. above indicates that most of the respondents $(73.1 \%)$ join business due to lack of employment opportunity followed by profitability of business scoring $14.2 \%$. However, only $7.6 \%$ of the respondents start business by considering support from government and $5.1 \%$ due to experience they had.

4.1.2. Response on work condition before starting business

The working condition of respondents before starting business has discussed in the table 4.5 below.

Table 4. 5. Working condition of respondents before starting business

\begin{tabular}{lccc} 
Did you have an employment before you start & & Frequency & Percentage \\
\cline { 2 - 4 } this business? & Yes & 29 & 14.7 \\
& No & 168 & 85.3 \\
\hline
\end{tabular}


The results given in the table 4.5 shows $85.3 \%$ of the respondents were unemployed before starting business whereas only $14.7 \%$ of them were employed. This shows that people from the community join business as an alternative in searching employment. On the other hand it also reveals that MSEs are creating job to those who are not employed in large.

\subsubsection{Favorability of business environment for MSEs}

The following table shows favorability of business environment for MSEs.

Table 4. 6. Favorability of business environment

How do you see the favorability of the business environment for MSEs?

\begin{tabular}{|c|c|c|c|c|c|c|}
\hline & Very good & Good & Medium & Low & Very low & Total \\
\hline Frequency & 6 & 27 & 47 & 51 & 66 & 197 \\
\hline Percentage & 3 & 13.7 & 23.9 & 25.9 & 33.5 & 100 \\
\hline
\end{tabular}

As indicated in table 4.6 above, most respondents (59.4\%) replied that the business environment was not favorable. On the other hand, very few respondents $(16.7 \%$ ) face favorable business environment and $23.9 \%$ of the respondents replied the favorability of the business environment was medium.

\subsubsection{Satisfaction level on services provided by different institutions}

The satisfaction level on services provided by different institutions is discussed in the table below.

Table 4. 7. Satisfaction level on services provided by different institutions

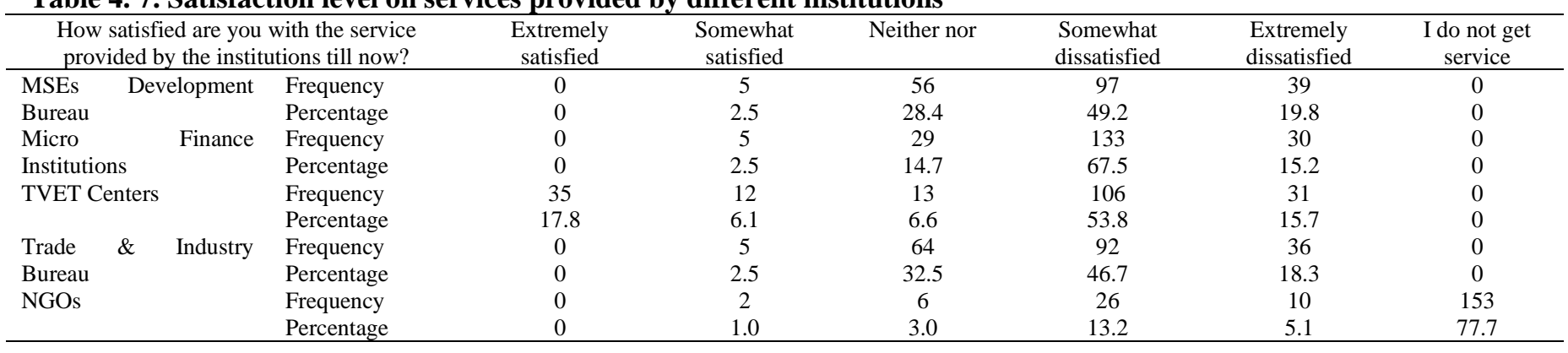

Table 4.7 reveals that very few respondents were somewhat satisfied to services given by the offices and only $17.8 \%$ of the respondents were extremely satisfied in services given by TVET centers among all service providing offices. On the other hand, only less than $33 \%$ of the respondents were neither satisfied nor dissatisfied. The table also shows that most respondents somewhat and extremely dissatisfied by the services provided by the stated offices. This shows that MSEs were not satisfied by the services they were getting from institutions. In addition, most respondents $(77.7 \%)$ indicated that they did not get any service from NGO's and from those who were getting services most of them $(13.2 \%)$ were somewhat dissatisfied by services they were getting.

4.1.5. Dependence of success on the support provider institution

The extent to which the business success depends on the service providing institution was shown in the table 4.8.

Table 4. 8. The extent of dependence of success on support providing organization

\begin{tabular}{|c|c|c|c|c|c|c|}
\hline & Very high & High & Medium & Low & Very low & Total \\
\hline Frequency & 38 & 32 & 70 & 40 & 17 & 197 \\
\hline Percentage & 19.3 & 16.2 & 35.5 & 20.3 & 8.6 & 100.0 \\
\hline
\end{tabular}

Table 4.8 shows most respondents $(35.5 \%)$ believed that the success of their enterprise depends highly and very highly on the support providing institutions. On the other hand, $35.5 \%$ of the respondents indicated that it had medium relationship contrary to this few respondents $(28.9 \%)$ indicated there was low and very low relation between their enterprise success and support providing institution. 
4.1.6. Sufficiency and source of capital to run their business

Sufficiency and source of capital to run MSEs were discussed using percentage analysis. The results were given in the following table.

Table 4. 9. Sufficiency and source of capital

Do you think the amount of your

current capital is sufficient to

run your business? What was your source of finance when you start your business?

\begin{tabular}{lccccccc} 
& Yes & No & $\begin{array}{c}\text { Own personal } \\
\text { saving }\end{array}$ & $\begin{array}{c}\text { Bank } \\
\text { loans }\end{array}$ & $\begin{array}{c}\text { From } \\
\text { relatives }\end{array}$ & $\begin{array}{c}\text { Micro Finance } \\
\text { loans }\end{array}$ & $\begin{array}{c}\text { Other, } \\
\text { specify }\end{array}$ \\
\hline Frequency & 3 & 194 & 65 & & 54 & 68 & Total \\
Percentage & 1.5 & 98.5 & 33.0 & & 27.4 & 34.5 & 10 \\
\hline
\end{tabular}

Table 4.9 above shows almost all respondents believed their capital was not enough to run their business. It shows MSEs were running their business in short of capital. The table also shows that the first source of capital for MSEs was Micro finance $(34.5 \%)$ followed by own savings $(33 \%)$ and relatives $(27.4 \%)$.

4.1.7. Finance related factors affecting businesses

The finance related factors which had impact on MSEs were analyzed using percentage. The results are given in the following table

Table 4. 10. Finance related factors

\begin{tabular}{|c|c|c|c|c|c|c|c|}
\hline $\begin{array}{l}\text { Please indicate in the box below, } \\
\text { finance related factors are affectin } \\
\text { business. }\end{array}$ & $\begin{array}{l}\text { te degree to which these } \\
\text { the performance of your }\end{array}$ & Very high & High & Medium & Low & No effect & Total \\
\hline \multirow{4}{*}{$\begin{array}{l}\text { Failure to apply financial } \\
\text { statements analysis } \\
\text { Unplanned withdrawal of cash for } \\
\text { personal use }\end{array}$} & Frequency & 93 & 69 & 31 & 4 & & 197 \\
\hline & Percentage & 47.2 & 35.0 & 15.7 & 2.0 & & 100 \\
\hline & Frequency & 87 & 25 & 71 & 10 & 4 & 197 \\
\hline & Percentage & 44.2 & 12.7 & 36.0 & 5.1 & 2.0 & 100 \\
\hline \multirow{2}{*}{$\begin{array}{l}\text { Poor management of working } \\
\text { capital }\end{array}$} & Frequency & 94 & 57 & 39 & 7 & & 197 \\
\hline & Percentage & 47.7 & 28.9 & 19.8 & 3.6 & & 100 \\
\hline \multirow{2}{*}{ Shortage of finance } & Frequency & 91 & 69 & 30 & 7 & & 197 \\
\hline & Percentage & 46.2 & 35.0 & 15.2 & 3.6 & & 100 \\
\hline
\end{tabular}

Table 4.10 reveals that most respondents $(82.2 \%)$ faced high and very high difficulty in applying financial statement analysis in their business followed by $15.7 \%$ who faced medium difficulty. From MSE respondents $56.9 \%$ made unplanned withdrawal of cash for personal use $36 \%$ made unplanned withdrawal at medium. Only, 5.1\% made unplanned withdrawal for personal use $2 \%$ faced no difficulty with unplanned withdrawal. On the other hand large number of respondents $(76.6 \%, 81.2 \%)$ had problem with management of working capital and financial shortage respectively.

4.1.8. License and process to get it

Table 4. 11. License and its process

\begin{tabular}{|c|c|c|c|c|c|}
\hline \multicolumn{2}{|l|}{ Do you have license for your business? } & \multicolumn{4}{|c|}{$\begin{array}{l}\text { If your answer to question number } 20 \text { is" No", what is your } \\
\text { reason }\end{array}$} \\
\hline Yes & No & High cost of license & $\begin{array}{r}\text { Lack of } \\
\text { awareness }\end{array}$ & Bureaucracy & Total \\
\hline Frequency & 17 & 2 & 15 & 0 & 17 \\
\hline Percentage & 8.6 & 11.8 & 88.2 & 0 & 100 \\
\hline \multicolumn{6}{|c|}{ Is there an improvement in license procedures in the past years? } \\
\hline Yes & No & I do not know & Total & & \\
\hline Frequency & 46 & 10 & 197 & & \\
\hline Percentage & 23.4 & 5.1 & 100 & & \\
\hline
\end{tabular}

Table 4.11 above indicates that most respondents $(91.4 \%)$ had license for their business and only $8.6 \%$ of the respondents did not have license. On the other hand, from those who did not have license, $88.2 \%$ did not have due to lack of awareness and the others $11.8 \%$ due to high cost of license. The table indicates also that more than half of the respondents $(65.5 \%)$ believed that the procedure to get license was improved and $23.4 \%$ responded that there was no improvement of procedure and lastly $5.1 \%$ did not know.

4.1.9. Acquiring working space

Working place acquirement ways were requested and discussed on the table below. 
Table 4. 12. Ways of acquiring working place

\begin{tabular}{|c|c|c|c|c|c|c|c|c|}
\hline \multicolumn{9}{|c|}{ How do you acquire the working space on which you operate your business? } \\
\hline & Bought & $\begin{array}{l}\text { Rented from } \\
\text { private owners }\end{array}$ & Leased & $\begin{array}{l}\text { Rented from those who obtained } \\
\text { the land from the government }\end{array}$ & $\begin{array}{l}\text { Given by } \\
\text { government }\end{array}$ & the & $\begin{array}{l}\text { Others, } \\
\text { specify }\end{array}$ & Total \\
\hline Frequency & 12 & 15 & & 76 & 94 & & & 197 \\
\hline Percentage & 6.1 & 7.6 & & 38.6 & 47.7 & & & 100 \\
\hline
\end{tabular}

As table 4.12 indicates, large number of respondents $(47.7 \%)$ got place on which they operate their business from government followed $(38.6 \%)$ by rent obtained from those who got land from government. Very few respondents $7.6 \%$ rented from private owners $6.1 \%$ bought for their business.

4.1.10. Attractiveness and sufficiency of working space

Table 4. 13. Working space related questions

\begin{tabular}{lcccc}
\hline & \multicolumn{2}{c}{$\begin{array}{l}\text { Do you think your location is in attractive business } \\
\text { area? }\end{array}$} & $\begin{array}{l}\text { Do you think this amount of space is enough for your day } \\
\text { to day business operation? }\end{array}$ \\
\cline { 2 - 5 } $\begin{array}{l}\text { Frequency } \\
\text { Percentage }\end{array}$ & Yes & No & Yes & 37 \\
& 15.2 & 167 & 160 & 18.8 \\
\hline
\end{tabular}

Table 4.13. above indicates that most respondents of MSEs $(84.8 \%)$ think that the location in which they are operating is not attractive. In addition, $81.2 \%$ the respondents responded that the space is not enough for their operation. This shows that from working place point of view, MSEs are not working in a conducive place.

\subsubsection{Problems and sources of finance}

Table 4. 14. Problems and sources of finance

\begin{tabular}{|c|c|c|c|c|c|c|c|c|}
\hline \multirow{2}{*}{\multicolumn{2}{|c|}{ Source of credit }} & \multicolumn{7}{|c|}{ Problems faced } \\
\hline & & \multirow{2}{*}{$\begin{array}{l}\begin{array}{l}\text { Long } \\
\text { process }\end{array} \\
68 \\
\end{array}$} & \multirow{2}{*}{$\begin{array}{l}\begin{array}{l}\text { Collateral } \\
\text { requirement }\end{array} \\
73 \\
\end{array}$} & \multirow{2}{*}{$\begin{array}{l}\text { Bureaucracy } \\
50 \\
\end{array}$} & \multirow{2}{*}{$\begin{array}{l}\begin{array}{l}\text { High } \\
\text { interest rate }\end{array} \\
59 \\
\end{array}$} & \multirow{2}{*}{$\begin{array}{l}\begin{array}{l}\text { Lack of } \\
\text { awareness }\end{array} \\
44 \\
\end{array}$} & \multirow{2}{*}{$\begin{array}{l}\begin{array}{l}\text { Small } \\
\text { loan } \\
\text { size }\end{array} \\
5 \\
\end{array}$} & \multirow{2}{*}{$\begin{array}{l}\text { Not tried } \\
123 \\
\end{array}$} \\
\hline Banks & Frequency & & & & & & & \\
\hline & Percentage & 34.52 & 37.06 & 25.38 & 29.95 & 22.34 & 2.54 & 62.44 \\
\hline \multirow[t]{2}{*}{ MFI } & Frequency & 111 & 117 & 149 & 112 & 29 & 105 & 56 \\
\hline & Percentage & 56.35 & 59.39 & 75.63 & 56.85 & 14.72 & 53.30 & 28.43 \\
\hline
\end{tabular}

As indicated in the table above, MSEs in western Hararghe faced difficulty in getting finance from banks and MFIs. Most of MSEs $62.44 \%$ did not tried to get loan from banks and those who tried faced difficulties of long process, collateral requirement, Bureaucracy and High interest rate. Getting finance from MFIs was also not easy. They were facing problems of long process $(56.35 \%)$, collateral requirement $(59.39 \%)$, Bureaucracy $(75.63 \%)$, High interest rate (56.85\%), Lack of awareness (14.72\%) and Small loan size $(53.30 \%)$.

\subsubsection{Competition of MSEs}

Table 4. 15. Level of competition

\begin{tabular}{|c|c|c|c|c|c|c|}
\hline \multicolumn{7}{|c|}{ How do you see the level of competition with other business organizations? } \\
\hline & Very high & High & Medium & Low & Very low & Total \\
\hline Frequency & 35 & 36 & 80 & 24 & 22 & 197 \\
\hline Percentage & 17.8 & 18.3 & 40.6 & 12.2 & 11.2 & 100 \\
\hline \multicolumn{7}{|c|}{ Who are your major competitors? } \\
\hline & Other MSEs & $\begin{array}{l}\text { Medium } \\
\text { enterprises }\end{array}$ & and & \multicolumn{2}{|c|}{ Importers and exporters } & Total \\
\hline Frequency & 51 & 120 & & \multirow{2}{*}{\multicolumn{2}{|c|}{$\begin{array}{l}26 \\
13.2\end{array}$}} & 197 \\
\hline Percentage & 25.9 & 60.9 & & & & 100.0 \\
\hline
\end{tabular}

Table 4.15. indicates that more than half $(76.7 \%)$ of the respondents responded that they faced competition at medium and more. In addition to that these respondents indicated that higher competition was from medium and large enterprises. On the other hand $25.9 \%$ of the respondents indicated that their competitors were other MSEs and lastly, very few respondents $(13.2 \%)$ indicated that their competitors were importers and exporters. 
4.1.13. Access and quality of infrastructure

The access and quality of infrastructure for MSEs has discussed in the table below.

Table 4. 16. Access and quality of infrastructure

\begin{tabular}{llllllll}
\hline \multirow{2}{*}{ Facility } & & Quality & & & & \\
\cline { 3 - 7 } & Very high & High & Medium & Low & Very low & Total \\
\hline \multirow{2}{*}{ Electricity } & Frequency & & 20 & 73 & 78 & 26 & 197 \\
& Percentage & & 10.2 & 37.1 & 39.6 & 13.2 & 100 \\
\multirow{2}{*}{ Water } & Frequency & & 5 & 89 & 76 & 27 & 197 \\
\multirow{2}{*}{ Telephone } & Percentage & & 2.5 & 45.2 & 38.6 & 13.7 & 100 \\
& Frequency & & 13 & 109 & 57 & 18 & 197 \\
\multirow{2}{*}{ Transport } & Percentage & & 6.6 & 55.3 & 28.9 & 9.1 & 100 \\
& Frequency & 8 & 12 & 75 & 77 & 25 & 197 \\
& Percentage & 4.1 & 6.1 & 38.1 & 39.1 & 12.7 & 100 \\
\hline
\end{tabular}

As table 4.16. shows, most respondents indicate that facilities of electricity, water, telephone and transport was medium and below. It shows $52.8 \%$ of electric, $52.3 \%$ of water, $38 \%$ telephone and $51.8 \%$ of transport facility was low and very low.

4.1.14. Availability of Business plan

The availability of business plan in MSEs has discussed in table ---below.

Table 4. 17. Availability of Business plan

\begin{tabular}{|c|c|c|c|}
\hline \multicolumn{4}{|c|}{ Does your company have a business plan? } \\
\hline & Yes & No & Total \\
\hline Frequency & 36 & 161 & 197 \\
\hline Percentage & 18.3 & 81.7 & 100 \\
\hline
\end{tabular}

Table 4.17 indicates most respondents $(81.7 \%)$ did not have business plan.

\subsubsection{Fairness of tax}

Table 4. 18. Tax related question

\begin{tabular}{cccc}
\hline Do you think that tax collectors are fair? & & \\
\hline & Yes & No & I have not paid yet \\
\hline Frequency & 46 & 134 & 17 \\
Percentage & 23.4 & 68.0 & 8.6 \\
\hline
\end{tabular}

Table 4.18. above indicates large number of respondents $(68 \%)$ believed that the tax was not fair whereas $23.4 \%$ responded it was fair and the rest $8.6 \%$ responded they did not paid yet.

4.1.16. Profitability and usage

Table 4. 19. Profit related questions

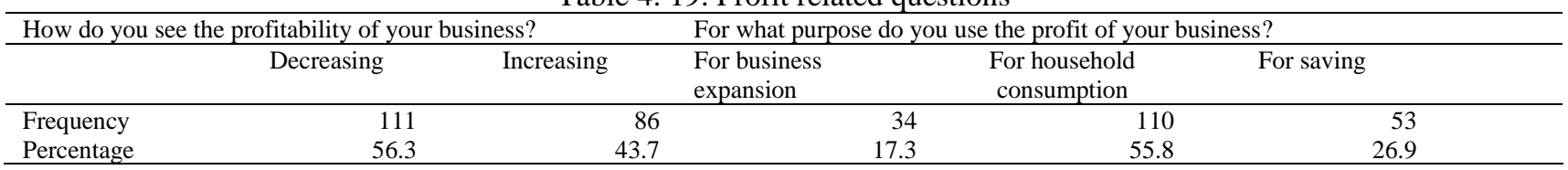

Table 4.19. indicates $56.3 \%$ of the respondents responded their profit was decreasing and $43.7 \%$ said it was increasing. On the other hand, more than half of the respondents $(55.8 \%)$ use their profit for household consumption followed by $26.9 \%$ who said they save their profit and only $17.3 \%$ of the respondents used for business expansion.

\subsubsection{Experience of MSEs owners}

Table 4. 20. Experience of MSEs

\begin{tabular}{lcc}
\hline \multicolumn{3}{l}{ Have you got enough experience from this business to start another business? } \\
\hline Frequency & Yes & No \\
Percentage & 139 & 58 \\
& 70.6 & 29.4 \\
\hline
\end{tabular}

As indicated in the table 4.20., most respondents (70.6\%) believed that they had got enough experience from their business to start even another business. 


\subsection{Interview results discussion}

Interview was conducted with MSE office heads. It was made for 10 wereda office heads. These were Chiro town, Boke, Tulo, Habro, Doba, Gemechis, Gubba koricha, Daro labu, Oda bultum. The same questions were raised for all. The first question was the way they classify MSEs based on capital as micro and small. All respondents clearly stated that they classify MSEs firstly by the kind of business they engaged in to five and stated Industry, service, agriculture, construction and merchandise. Except for construction and Industry those having a capital of up to 50,000 were classified under micro and from 50,000 to 100,000 as small. For construction and Industry, those having capital up to 100,000 are micro and from 100,000 to 500,000 were classified under small. Their answer for the second question i.e how they classify MSEs based on number of employees/members was also discussed similarly. All respondents discussed those MSEs having up to 5 members were classified under micro and those having from 6 to 50 were classified under small. The other question raised was about the ownership form of the business. All respondents discussed their office works only with those having more than one ownership. Proprietorship kind was not included for such kind of support.

Question on why people want to join MSEs was raised for each. All of the respondents believed that most of the people came to them due to lack of employment opportunity on the other hand some of the respondents told few people came by knowing the profitability of the business specially in industry kind MSEs. They also discussed that almost all who came to join the business were unemployed.

Question was raised to check the favorability of business environment for MSEs. Among the ten interviewees, six mentioned that the environment was good, support from government on different cases like acquisition of operating area, different trainings and facilitation of loan was there to support them. Two of the respondents express that even though support was provided it was not so much satisfying. The rest two respondents explained that the favorability was very low. They explained the office was trying to support them based on the rule and regulation of MSEs. However, the office could not provide support as needed. They stated that MSEs were not convenient with the working place the office was providing. In addition, to get loan from micro finance institution they had to have collateral which the individuals took it as a difficulty as most of them were unemployed. They also explained that the trainings provided by TVET centers were not supporting the MSEs to fill their skill gap.

For issue raised about the dependence of the success of MSEs on support providing institution all explained that it depends. They told that most of the members of MSEs were unemployed people; these people did not have enough capital to run their business. The amount of capital required from the owners to get loan was $10 \%$ of the total capital needed. For the rest amount they seek loan mostly from micro finance institutions. When they ask loan they have to prepare business plan. However the people could not prepare the business plan and experts from the office prepare business plan and gave them to get loan. The micro finance institutions reduce the amount of capital requested by the individuals to at least half. At the end they cannot operate what they want due to lack of capital. And lastly, they explained, the success of their business depends on the capital they had to operate their business. Only one wereda i.e. Daro labu explained that MSEs got financial support from NGO.

Question on work place acquisition, attractiveness of the place and sufficiency of the place was asked. They all explained that their office provides work place depending on the kind of MSEs. However, the place they were providing was not enough and in addition not attractive. They were providing them just to provide and even cannot facilitate good places.

Concerning competition respondents raised that competition from medium and large enterprises was the one on which they were suffering.

Issues on different infrastructures were discussed during interview. Accordingly, five interviewees explained, water and electricity facility were low and very low level and telephone and transport was medium. Other three interviewees explained all the four facilities found at medium level. Two explained that transport facility was very low.

Question on fairness of tax was raised for the interviewees. Seven interviewees agree that there was gap on tax collection. They were considered just as any other merchants and no favor was there for MSEs.

Lastly, question on experiences of MSEs and what it supported them was asked. The respondents explained members of MSEs had got enough experience from their business. Some had changed their business by identifying successful business areas.

\subsection{Comparison of MSEs based on their experience}

4.1.18. Comparison of MSEs based on the time of establishment

Table 4. 21. Comparison of MSEs employment history based on experience

\begin{tabular}{llcccccc}
\hline Variable & Institution & $\mathrm{N}$ & $\mathrm{M}$ & $\mathrm{SD}$ & $\mathrm{SEd}$ & $\mathrm{t}$-value & $\begin{array}{l}\text { Significance } \\
\text { Level(2tailed) }\end{array}$ \\
\hline Employment before & 2005 \& before & 38 & 1.82 & .393 & & & \\
joining business & 2006 up now & 159 & 1.86 & .346 & .346 & -0.661 & $\mathrm{P}>0.05$ \\
\hline
\end{tabular}

$\mathrm{df}=\mathrm{N} 1+\mathrm{N} 2-2=195, \mathrm{df}=$ Degree of Freedom, $\mathrm{N}=$ Number of Sample, $\mathrm{M}=$ Mean, $\mathrm{SD}=$ Standard

Deviation, $\mathrm{SEd}=$ Standard Error of Difference

The results given Table 4.21. show the employment history of MSE owners did not vary significantly based on time. The tvalue obtained, assuming equal variance between the groups, is -0.661 , which is statistically not significant. The mean MSEs started 2005 and before and those who started 2006 and working up to now was 1.82 and 1.86 with standard deviation of 0.393 and 0.346 respectively and standard error difference was 0.346 . 
Thus it can be concluded from the table that there was no significant difference in the employment history of both who started the business at 2005 \& before and working from 2006 up to now. Hence table 4.5. and table 4.21 lead to the conclusion that people join MSEs due to lack of alternative employment opportunity.

4.1.19. Comparison of fairness of tax based on establishment time

Table 4. 22. Fairness of tax based on establishment time

\begin{tabular}{|c|c|c|c|c|c|c|c|}
\hline Variable & Institution & $\mathrm{N}$ & M & SD & SEd & t-value & $\begin{array}{l}\text { Significance } \\
\text { Level(2tailed) }\end{array}$ \\
\hline \multirow[b]{2}{*}{ Fairness of tax } & $2005 \&$ before & 38 & 1.74 & .446 & \multirow[b]{2}{*}{.035} & \multirow[b]{2}{*}{-.066} & \multirow[b]{2}{*}{$\mathrm{P}>0.05$} \\
\hline & 2006 up now & 159 & 1.74 & .439 & & & \\
\hline
\end{tabular}

The results on the table 4.22. show the t-value of -0.66 assuming equal variance between the groups and mean tax fairness of MSEs established 2005 \& before 1.74 and 2006 up now 1.74 at a standard deviation of $0.446 \& 0.439$ respectively. The result obtained shows that there was no significant difference between MSEs established 2005 \& before and those established at 2006 on wards on fairness of tax.

Thus table 4.22. and table 4.18 indicated that tax paid by MSEs was not fair.

4.1.20. Comparison using profitability

Table 4. 23. Profitability based on establishment time

\begin{tabular}{|l|l|l|l|l|l|l|l|}
\hline Variable & Institution & $\mathrm{N}$ & $\mathrm{M}$ & $\mathrm{S}$ & $\mathrm{S}$ & $\mathrm{t}$ & $\begin{array}{l}\text { Significance } \\
\text { Level(2tailed) }\end{array}$ \\
\hline \multirow{3}{*}{ Profitability } & 2005 \& before & 38 & 1.45 & .504 & & & \\
\cline { 2 - 9 } & 2006 up now & 159 & 1.43 & .497 & .039 & .148 & $\mathrm{P}>0.05$ \\
\hline
\end{tabular}

The results on the table 4.23. reveals the t-value of 0.148 assuming equal variance between the groups and mean profitability of MSEs established 2005 \& before 1.45 and 2006 up now 1.43 at a standard deviation of $0.504 \& 0.497$ respectively. The result obtained shows that there was no significant difference between MSEs established 2005 \& before and those established at 2006 on wards profitability.

Hence table 4.23. and table 4.19 indicated that profitability in MSEs did not vary based on establishment time.

\subsection{Summary}

\section{SUMMARY AND CONCLUSION}

The present study was designed to investigate the Problems, Prospects and the role of Micro and Small Enterprises in economy. It was employed in the case of Western Hararghe An attempt was also made to identify the difference among MSEs based on establishment time.

The target population of this study consisted of MSEs found in western Hararghe. Accordingly, the owners of MSEs and MSE development officers were included. A Stratified random sampling method was used to give chance to every MSEs found in different weredas. In addition to this, available sampling method was used to include office heads of MSE development office of the weredas.

To conduct this study, both qualitative and quantitative data were used. Quantitative data were collected on the personal characteristics of respondents, business profiles and basic business information of MSEs using questionnaire whereas qualitative data were collected using interview from MSE development heads to supplement the quantitative data. The quantitative data was analysed using frequency and independent sample t-test analysis using SPSS. The data collected through interview were analysed using narration.

Independent sample t-tests were employed to compare the mean scores of MSEs established before 2005 and those established after 2006. From this study the following major findings have been drawn.

Respondents of MSES having a higher percentage for lack of employment opportunity and no employment before joining the business, i.e. $73.1 \%$ \& $85.3 \%$ respectively, believed that they joined the MSE mainly because of lack of employment opportunity. Result from the t-test shows there was no significant difference between those who joined the business in 2005 and before and those who joined in 2006 and later.

Favorability of business environment for MSEs was also analysed. The analysis shows that the business environment was not conducive for MSEs scoring a higher percentage i'e. 59.4\%.

Most respondents i.e. more than 50\% of MSEs were not satisfied with the service provided by different institutions. 
MSEs indicated that the success of their enterprise $71 \%$ depended on the support providing institution very highly, highly and at medium level. This indicates that the success of the MSEs depend on support providing institutions. This was clearly supported by data obtained from interview. The interviewees stated that the MSEs cannot get the amount of capital they needed. Thus, their success depends on capital they obtained and the capital they obtained matters their work.

Analysis about the sufficiency of capital revealed almost all MSEs i.e. $98.5 \%$ could not get sufficient capital. The analysis also indicated, the first source of capital for MSEs was micro finance institution and personal saving having 34.5\% and 33\% respectively.

The study had also analysed the finance related problems and identified that most MSEs i.e $82.2 \%$ failed to apply financial statement analysis highly and very highly. At the same time 56.9\% of these MSEs made unplanned withdrawal of cash for personal use. Results of the analysis also show that, large number of MSEs i.e 76.6\% manage their working capital poorly and $81.2 \%$ faced shortage of finance very highly and highly.

Result of analysis indicated that almost all MSEs had business license whereas very few MSEs i.e 8.6\% did not had. From those who did not have licence, $88.2 \%$ indicated that they lack awareness on license. On the other hand, $65.5 \%$ believed that the procedure to get license had become better.

Analysis from the study indicated that most MSEs 47.7 obtained working space from government. Next to those who got from government $38.6 \%$ indicated they acquire their working space by renting from those who obtained from government. However, the result indicated most of them $84.8 \%$ were working in a place where it was not attractive for their business. In addition to that most MSEs $81.2 \%$ were working in a place where the area was not enough to perform their day to day business activity.

Most MSEs in western Hararghe $76.7 \%$ faced competition at medium and more level. The result indicated this competition was highly from (60.9\%) from medium and large enterprises.

Analysis about availability of business plan indicated that most MSEs $81.7 \%$ did not have business plan. In addition to this, result on tax fairness $68 \%$ indicated that there was no fairness on tax payment.

Profitability of MSEs was analysed and the result indicated almost around half i.e 56.3 of MSEs's profit was decreasing and $43.7 \%$ of them had an increasing profit margin. The result also revealed that from the profit they obtained, 55.8\% was used for home consumption.

At the end the study identified that most MSEs 70.6 had got enough experience which can help them to go for search of new job. It indicated that MSEs work on development of entrepreneurial skill.

\subsection{Conclusions}

Conclusions were drawn on the basis of findings of the data analysis. The Problems, Prospects and the role of Micro and Small Enterprises in economy in the case of Western Hararghe had been identified and concluded. The conclusions were:

$\checkmark$ Most of the MSEs in western Hararghe were partnership kind and were owned mostly by 1-5 members.

$\checkmark$ Many of the businesses were started due to lack of employment opportunity. Thus, unemployment was the main reason to start business in western Hararghe.

$\checkmark \quad$ Favourability of business environment was not good for MSEs.

$\checkmark$ MSEs in western Hararghe got support from different institutions but the amount they got was not enough to perform what they wanted. Hence, the success of the MSEs depends on the support providing institutions.

$\checkmark$ MSEs in western Hararghe failed to apply financial statement analysis, made unplanned withdrawal of money for personal use, manage their working capital poorly and faced shortage of finance.

$\checkmark$ MSEs in western Hararghe had licences for their business.

$\checkmark$ MSEs in western Hararghe did not get working space and even the working spaces given were not attractive and sufficient for work.

$\checkmark$ MSEs in western Hararghe had problems in getting finance from both bank and micro finance institutions. MFIs had long process, bureaucracy and require collateral. In addition, they provided small loan which is not enough for their business need.

$\checkmark$ MSEs in western Hararghe had competition it was highly from medium and large enterprises.

$\checkmark$ Facilities of electric, water, telephone and transport were not sufficient and needs further job.

$\checkmark$ MSEs in western Hararghe paid taxes but the amount was not fair.

$\checkmark$ MSEs in Western Hararghe were profitable at decreasing rate and spent their profit mostly for home consumption.

$\checkmark$ Regardless of the challenges MSEs in western Hararghe were facing, they got experiences which will help them in entrepreneurial development.

\subsection{Recommendations}

Based on the major findings indicated in the analysis, recommendations have been drawn with the view to improve the role of micro and small enterprises in contribution to employment, income generation and entrepreneurial development.

Deep emphasis should be given to MSEs in western Hararghe in solving financial problems, problems of facilities like working space, electricity, water, transport \& telephone and skill gaps. 


\section{REFERENCES}

[1] Beck, T., and Demirguc-Kunt, A. (2006).“Small and Medium-Size Enterprises: Access to Finance as a Growth Constraint,” Journal of Banking \& Finance, vol. 30(11), pages 2931-2943.

[2] Bigsten, A., Peter Kimuyu, and Karl Lundvall, (2000), Are Formal \& Informal Small Firms Really Different? Evidences from Kenyan Manufacturing, Institute of Policy Analysis \& Research, Nairobi, Kenya.

[3] CBS (Central Bureau of Statistics), (1999), National Micro and Small Enterprise Baseline Survey 1999, International Center for Economic Growth (ICEG), and K-Rep Holdings Ltd, Survey Results, CBS, Kenya, Nairobi.

[4] Coleman, James, (1988), "Social Capital in the Creation of Human Capital", American Journal of Sociology, 94 (supplement) 95-120.

[5] Coleman, James, (1990), Foundations of Social Theory. Cambridge, Mass: Harvard University Press

[6] CSA, (2004), Report on Urban Informal Sector Sample Survey, October 2004, Statistical Bulletin Number 282, Addis Ababa, Ethiopia.

[7] CSA, (2011), Ethiopia Demographic and Health Survey (EDHS), Preliminary Report, Addis Ababa, Ethiopia.

[8] Fachamps, M and B. Minten, (1999), "Social Capital and the Firm: Evidence from Agricultural Trade", Department of Economics, Stanford University press, Stanford.

[9] Fafchamps, M. and B. Minten, (2003), "Relationship and Traders Madagascar", International Food Policy Resources Institute, MSSD Discussion paper No. 24.

[10] Fukuyama, F., (1995), “Trust: The Social Capital Virtue and the Creation of Prosperity", the Free Press Paperbacks, New York.

[11] Giddens, Anthony, (1989) Sociology and McNeill, P. Research Methods, London, Routledge.

[12] Hibret, N. (2009), Impact of Business Development Services in Local Economic Development: The case of Gulale Handloom MSE in City Place. Masters Thesis, Institute of Social Studies (ISS), Graduate School of Development Studies, The Hague, Netherlands.

[13] Hussmanns, Ralf (2001): Informal sector and informal employment: elements of a conceptual framework; Paper presented at the Fifth Meeting of the Expert Group on Informal Sector Statistics (Delhi Group), New Delhi, 19-21 September 2001.

[14] Hussmanns, Ralf (2002): A labour force survey module on informal employment (including employment in the informal sector) as a tool for enhancing the international comparability of data; Paper presented at the Sixth Meeting of the Expert Group on Informal Sector Statistics (Delhi Group), Rio de Janeiro, 16-18 September 2002.

[15] ILO, (2002a).ILO compendium of official statistics on employment in the informal sector. Geneva, Switzerland: ILO. (STAT working paper, no. 1.) Prologue. Survey of MSEs in Selected Major Urban Areas of Ethiopia

[16] ILO, (1973), "Employment and Unemployment in Ethiopia", Report of the Exploratory Employment Policy Mission organized by the ILO and financed by the United Nations Development Program (UNDP), Geneva.

[17] ILO/JASPA (1993), "Ethiopia Towards Sustained Employment Promotion", World Employment Programme, Report of an ILO-TSSI Mission on Employment and Human Resources Development in Ethiopia. Addis Ababa.

[18] ILO, (2000), ILO activities concerning the informal sector: thematic evaluation. Geneva, Switzerland: ILO. (GB.277/ESP/1/1.) www.ilo.org/public/ english/standards/relm/gb/docs/gb277/pdf/esp-1-1.pdf

[19] ILO, (2000): Resolution concerning statistics of employment in the informal sector, adopted by the Fifteenth International Conference of Labour Statisticians (January 1993); in: Current International Recommendations on Labour Statistics, 2000 Edition; International Labour Office, Geneva, 2000

[20] ILO, (2002b). Decent work and the informal economy: abstracts of working papers. Geneva, Switzerland: ILO, Employment Sector.

[21] ILO, (2003): Guidelines concerning a statistical definition of informal employment, endorsed by the Seventeenth International Conference of Labour Statisticians (November-December 2003); in: Seventeenth International Conference of Labour Statisticians (Geneva, 24 November - 3 December 2003), Report of the Conference; Doc.ICLS/17/2003/R; International Labour Office, Geneva, 2003.

[22] ILO, (2003a). Ethiopian Women Entrepreneurs: Going for Growth. ILO Sub-regional Office, Addis Ababa and Ministry of Trade and Industry, Women's Affairs Department in association with SEED, ILO, Geneva.

[23] ILO, (2004) World Employment Report 2004-2005: Employment, Productivity and Poverty Reduction Technical Report. ILO, Geneva.

[24] Kefale\&Chinnan, (2012), Employement Growth and Challenges in Small \& Micro Enterprises: Woldiya, North-East Amhara Region, Ethiopia, Educational Resarch and Essays Vol. 1(2).

[25] McCormick, Dorothy (2008), Micro and Small Enterprises in Africa: Characteristics and Contribution to Development, Institute for Development Studies, University of Nairobi, Kenya.

[26] Mead, D. D., \&Lieadholm, C. (1998).The dynamics of micro and small enterprises in developing countries. World Development, 24(3),481-487.

[27] MoFED, (2005), Ethiopia: The Millennium Development Goals (MDGs) Needs Assessment Synthesis Report, December 2005, Addis Ababa.

[28] MoFED, (2006), Ethiopia: Building on Progress A Plan for Accelerated and Sustained Development to End Poverty (PASDEP), (2005/06-2009/10), September, 2006, Addis Ababa. Survey of MSEs in Selected Major Urban Areas of Ethiopia.

[29] MoFED, (2010), Growth and Transformation Plan 2010/11 - 2014/2015, November, 2010, Addis Ababa.

[30] Moyi, E. and Njiraini, P. (2005), Towards Technology Models for Micro and Small Enterprises in Kenya: Common Principles and Best Practices. Discussion Paper No 51, Productive Sector Division, Kenya Institute for Public Policy Research and Analysis, Nairobi, Kenya.

[31] Nichter, Simeon \&Goldmark, Lara, (2005), Understnding Micro and Small Enterprises Growth, USAID microREPORT No. 36, www.microLINKS.org.

[32] Nogare, LD (2006), Grow or Go: a theory Building Study Regarding The Survival and Growth of Micro and Small Enterprises. PHD Thesis, Southern Cross University, WerbedruckPetzold, Gernshiem, Germany.Order No. 15/1957: An Order to Establish "Ministry of Community Development".

[33] Putnam, Robert, (1995),’Bowling alone: America's Declining Social Capital”, Journal of Democracy, 6 (11) 65-87.

[34] Ranis, G. (2004), the Evolution of Development Thinking: Theory and Policy, Discussion Paper No 886, Ecomomic Growth Cenetr, Yale University, New haven, CT, USA

[35] Rossman, Gretchen B. and Rallis, Sharon F., (1998) Learning in the Field: An Introduction to Qualitative Research, London, Sage Publications, Inc.

[36] Tambunan, T. (2006), Micro, small, and Medium Enterprises and Economic Growth. Working paper Series No 14, Center for Industry and MSE Studies, Faculty of Economics, University of Trisakti.

[37] Teshome Mulat, (1991), "The Relationship between Wages and Employment: A Survey", International Journal of Development Planning Literature; Vol. 6, Nos. 3-4: 231-238.

[38] Teshome Mulat, (1994), "Institutional Reform, Macroeconomic Policy Change and the Development of Small Scale Industries in Ethiopia", Stockholm School of Economics, Working Paper No.23, Stockholm.

[39] Thobeche, E. (2000), The Evolution of Development Doctrine: 1950 - 2005.

[40] Tybout, J. R. (2000). Manufacturing firms in developing countries: How well do they do, and why? Journal of Economic Literature, 38(1), 11-44.

[41] White, Simon (1999), "Micro and Small Enterprise Development \& Poverty Alleviation in Thailand", Working Paper 3, (Produced as part of ILO/UNDP Project on MSE Development and Poverty Alleviation in Thailand (THA/99/003).

[42] William, John van, et al., eds., (1989), Making Our Research Useful: Case Studies in the Utilization of Anthropological Knowledge, London \& Colorado, Westview Press, Inc.

[43] World Bank, (2002), "Social Capital for Development". http//www.worldbank.org/poverty/scapital/index.htm.

[44] Yamane, T., 1967.Statistics, an introductory analysis, 2nd Ed. Harper and Row, New York. 


\section{APPENDICES}

\subsection{Appendix I}

\section{Questionnaire}

\section{GENERAL DIRECTION}

The main purpose of this questionnaire is to identify Problems, Prospects and the role of Micro and Small Enterprises in economy. The case of Western Hararghe. The information obtained will help to identify whether there are Problems and Prospects and try to identify the role of Micro and Small Enterprises in economy in the specified place.

To obtain reliable and valid information for the research, your open and genuine response is highly appreciated. Your responses will be kept confidential. It is for identification of existing status of MSEs.

\section{DO NOT WRITE YOUR NAME ON THE QUESTIONNAIRE.}

Thank you for your cooperation!

\section{Part One: General information}

Provide your answer by underlining or encircling your choice.

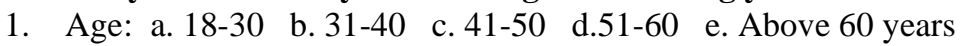

2. Sex: a. Male b. Female

3. Marital status: a. Unmarried b. Married c. Divorced d. Widowed

4. What is your educational level? a. Does not read and write b. Read and write
c. Elementary School
d. Secondary School
e. TVET graduate
f .College diploma
g. First degree and above

$\begin{array}{lll}\text { 5. Size of your business: 1. Micro 2. Small } & \end{array}$

6. Year of establishment of your business: E.C

7. Number of members you have in your business:

a. at start upb. At this time

8. What is the nature of your business? 1. Proprietorship

\section{Partnership}

9. What are factors motivated you to involve in this business? (More than one answer is possible)

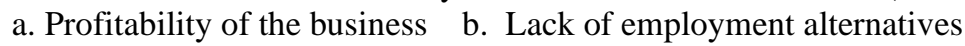

c. Good government support d. Previous experience

10. Did you have an employment before you join this business?

$$
\begin{array}{ll}
\text { a. Yes } & \text { b. No }
\end{array}
$$

\section{Part Two: Basic Business Information}

11. How do you see the favorability of the business environment for MSEs?
a. Very good
b. Good
c. Medium
d. Low
e. very low

12. Compared to your expectations, how satisfied are you with the service provided by the institutions till now?

\begin{tabular}{|l|l|l|l|l|l|l|l|}
\hline $\begin{array}{c}\text { S/ } \\
\text { N }\end{array}$ & Type of services & $\begin{array}{l}\text { Extremely } \\
\text { satisfied }\end{array}$ & $\begin{array}{l}\text { somewhat } \\
\text { satisfied }\end{array}$ & Neither no & $\begin{array}{l}\text { Some what } \\
\text { Dissatisfied }\end{array}$ & $\begin{array}{l}\text { Extremely } \\
\text { dissatisfied }\end{array}$ & $\begin{array}{l}\text { I do not get } \\
\text { service }\end{array}$ \\
\hline & MSEs Development Bureau & & & & & & \\
\hline & Micro Finance Institutions & & & & & & \\
\hline & TVET Centers & & & & & & \\
\hline & Trade \& Industry Bureau & & & & & & \\
\hline & NGOs & & & & & & \\
\hline
\end{tabular}

13. To what extent your business successes depend on the support provider institutions?
a. Very high
b. High
c. Medium
d. Low
e. Very low

14. Amount of your capital in Birr
a. At start up
b. Now-

15. Do you think the amount of your current capital is sufficient to run your business?

a. Yes b. No

16. If your answer to question number 15 is "No", how much money in Birr would be sufficient to run your business?

17. What was your source of finance when you start your business? (More than one
answer is possible).
a. Own personal saving
b. Bank loans
c. from relatives
d. Micro Finance loans
e. Other, specify

18. Do you separate the household and the business expenses?

a. Yes b. No

19. Please indicate in the box below, the degree to which these finance related factors are affecting the performance of your business. 


\begin{tabular}{|l|l|l|l|l|l|l|}
\hline $1 / \mathrm{k}$ & Financial factors & Very high (1) & High (2) & Medium (3) & Low (4) & No effect (5) \\
\hline 1 & $\begin{array}{l}\text { Failure to apply financial statements } \\
\text { analysis }\end{array}$ & & & & & \\
\hline 2 & $\begin{array}{l}\text { Unplanned withdrawal of cash for } \\
\text { personal use }\end{array}$ & & & & & \\
\hline 3 & Poor management of working capital & & & & & \\
\hline 4 & Shortage of finance & & & & \\
\hline
\end{tabular}

20. Do you have license for your business? a. Yes

b. No

21. If your answer to question number 20 is" No", what is your reason?
a. High cost of license
b. Bureaucracy
c. Lack of awareness
d. Others

22. Is there an improvement in license procedures in the past years?
a. Yes
b. No
c. I do not know

23. How do you acquire the working space on which you operate your business?
a. Bought
b. Rented from private owners
c. Leased
d. Rented from those who obtained the land from the government

e. Given by the government

f. Others, specify

24. Do you think your location is in attractive business area? a. Yes b. No

25. Do you think this amount of space is enough for your day to day business operation?
a. Yes
b. No

26. What problems do you face in borrowing money from banks and MFI?

\begin{tabular}{|l|l|l|l|l|l|l|l|}
\hline \multirow{2}{*}{\begin{tabular}{l} 
Source $\begin{array}{l}\text { of } \\
\text { credit }\end{array}$ \\
\cline { 2 - 7 }
\end{tabular}} & $\begin{array}{l}\text { Long } \\
\text { process (1) }\end{array}$ & $\begin{array}{l}\text { Collateral } \\
\text { requirement (2) }\end{array}$ & $\begin{array}{l}\text { Bureaucracy } \\
(3)\end{array}$ & $\begin{array}{l}\text { High } \\
\text { interest rate } \\
(4)\end{array}$ & $\begin{array}{l}\text { Lack of } \\
\text { awareness } \\
(5)\end{array}$ & $\begin{array}{l}\text { Small } \\
\text { loan } \\
\text { size (6) }\end{array}$ & $\begin{array}{l}\text { other } \\
\text { Banks }\end{array}$ \\
\hline MFI & & & & & & & \\
\hline
\end{tabular}

27. How do you see the level of competition with other business organizations?
a. Very high
b. High
c. Medium
d. Low e. Very low

28. Who are your major competitors? (more than one(1) answer is possible)

a. Other MSEs b. Medium and large enterprises c. Importers and exporters

29. How do you evaluate the access and quality of the following infrastructures?

\begin{tabular}{|c|c|c|c|c|c|c|}
\hline \multirow[t]{2}{*}{ sn } & \multirow[t]{2}{*}{ Facility } & \multicolumn{5}{|l|}{ Quality } \\
\hline & & $\begin{array}{l}\text { Very high } \\
\text { (1) }\end{array}$ & $\begin{array}{l}\text { High } \\
\text { (2) }\end{array}$ & Medium(3) & Low(4) & $\begin{array}{l}\text { Very } \\
\text { low(5) }\end{array}$ \\
\hline 1 & Electricity & & & & & \\
\hline 2 & Water & & & & & \\
\hline 3 & Telephone & & & & & \\
\hline 4 & Transport & & & & & \\
\hline
\end{tabular}

30. Does your company have a business plan? a. Yes b. No

31. Please indicate the degree to which these marketing factors are affecting the performance of your business.

\begin{tabular}{|l|l|l|l|l|l|l|}
\hline S/N & Marketing factors & Very high (1) & High (2) & Medium (3) & Low (4) & No effect (5) \\
\hline 1 & Lack of skill to set competitive price & & & & & \\
\hline 2 & Poor location & & & & \\
\hline 3 & Demand forecasting & & & & & \\
\hline 4 & $\begin{array}{l}\text { Lack of product diversity and inability to } \\
\text { modify existing products }\end{array}$ & & & & & \\
\hline 5 & Poor customer handling and relationship & & & & & \\
\hline 6 & sales skill staffs & & & & \\
\hline 7 & Ability to promote the products distribution channel and & & & & & \\
\hline 8 & $\begin{array}{l}\text { Efficient } \\
\text { networking }\end{array}$ & & & & & \\
\hline
\end{tabular}

32. Do you think that tax collectors are fair? a. Yes

b. No c. I have not paid yet

33. How do you see the profitability of your business? 1. Decreasing 2. Increasing

34. For what purpose do you use the profit of your business? a. For business expansion

b. For household consumption c. For saving d. Others --------------

36. Have you got enough experience from this business to start another business? 
$\begin{array}{ll}\text { a. yes } \quad \text { b. no } & \end{array}$

Thank you again for taking your valuable time to complete the questionnaire!

\subsection{8 .}

Appendix II

\section{Unkaa gaafille}

Gaaffileen armaan gadii kun daataa barbaachisoo ta'aan qoranno dhimma interprizota maykiroo fi xixiqqaa irratti hojatamuuf argachuuf kan qoophaa'e yeroo ta'u haqummaan deebii isiin laattan qulqullina qorannichaaf barbaachisa dha. Deebiin isiin laattan qaama kan biraaf darbee waan hin keennamneef garaa gutuun irratti yaada keessan kennuuf of hin qusatinaa.

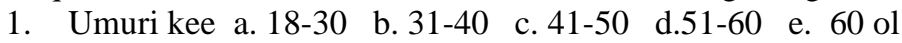

2. Saalaa kee a. Dhalaa/dubara b. Dhira

3. Haala maatii kee a. kan heerumne/funee b. kan fudhe/heerumte
c. kan wal hike
d. du'aan kan adda ba'e

4. Haala barnoota kee a. barreesuuf dubbisu kan hin dandeenye

b. barreesuuf dubbisu kan danda'u c. barnoota sadarkaa jalqabaa

d. barnoota sadarkaa lammaffaa e. barnoota sadarkaa ogummaafi Technikaa

f. diiploomaa kolleejjii g. barnoota diigrii lammaffaa fi isaa ol

5. Sadarkaan mana daldalaa kee kam keessatti ramadama
a. Micro/xixiqqaa
b. Small /Xiqqaa

6. Bara itti hundeefame A.L.H

7. Baay'iina miseensoota mana daldalicha a. Yeroo eegalaa

8. Manni daldalaakee kam keessatti ramadamaa

a. Kan dhunfaa nama tokkoo/proprietorship

b. Kan dhuunfaa nama lamaaf isaa olii/partnership

9. Sababoota hojii daldalaatti akka seentu sigodhan (deebiin tokkoo ol ni dandaa'ama)
a. Buu'aa qabaachu daldalaa
b. Carraa qacarri hojii dhabu
c. Deggarsii mootummaa gaarii ta'uu
d. Muxannoo qabdu

10. Dalagaa kannatti osoo hin seeniin dura hojii qabdaa?
a. Eeyyee
b. hin qabu

11. Haalli jiru hojii enterprizii micro fi Xixiqa mijataa ta'uu isaa
a. Baay'ee gaarii
b. gaarii
c. giddu galeessa d. xiqqaa
e. baay'ee xiqqaa

12. Tajaajila waajjiraaleen armaan gadi kennan akka fedha keetti hangam qubsaa dha?

\begin{tabular}{|l|l|l|l|l|l|l|l|}
\hline $\begin{array}{l}\text { la } \\
\mathrm{k}\end{array}$ & Akaakuu tajaajilaa & $\begin{array}{l}\text { Baay'ee } \\
\text { qubsaa }\end{array}$ & $\begin{array}{l}\text { Hanga } \\
\text { barbaachisu } \\
\text { qubsaa } \\
\text { dha/ga'aa dha }\end{array}$ & $\begin{array}{l}\text { Qubsaas } \\
\text { gaddisiisaas } \\
\text { miti }\end{array}$ & $\begin{array}{l}\text { Hanga } \\
\text { barbaachisu } \\
\text { qubsaa miti }\end{array}$ & $\begin{array}{l}\text { Baay'ee qubsaa } \\
\text { kan hin taane }\end{array}$ & $\begin{array}{l}\text { Fayyadam } \\
\text { aa } \\
\text { waajjirich } \\
\text { aa } \\
\text { miti } \\
\text { miti }\end{array}$ \\
\hline 1 & Waajjira Enterprizii xixiqqaa & & & & & & \\
\hline 2 & Waldaa Qusannaafi liiqii & & & & & & \\
\hline 3 & Collejjii tekniikaa fi ogummaa & & & & & & \\
\hline 4 & $\begin{array}{l}\text { Waajjira daldalaa fi } \\
\text { industrii }\end{array}$ & & & & & \\
\hline 5 & Wajjiroota mit-mootummaa & & & & & & \\
\hline
\end{tabular}

13. Bu'a qabeessummaan dalagaa kee hangam waajjiraalee qarshii siif kennan irratti hundaa'a?
a. baay'ee guddaa
b. Guddaa
c. giddu galeessa
d. xiqqaa
e. baay'ee xiqqaa

14. Caapitaala qabdu

a. Eegala dalagaakee irratti

b. yeroo ammaa

15. Caapitaalli amma qabduu hojii kee raawwachuuf ga'aa dha jettee amantaa?
a. Eeyyee
b. lakki

16. Deebiin kee lakk 15 lakkii yoo ta'ee caapitaala hangamiitu na ga'a jettee yaaddaa ?(birriitiin)?

17. Maddi qarshii eegala hojii keef turee kami?
a. Qusannaa ofii
d. Liqii baankiiti
b. Firoota
e. Liqii interpiraayizii maykiroo xixiqqaa
c. Kan biraa yoo ta'ee ibsi

18. Basii manaa fi kan daldala kee adda baastee qabataa?
a. Eeyyeen
b. Lakki

19. Gabatee armaan gadii keessatti warren ibsaman hangam dhibbaa dalagaa keerratti akka ga'aan agarsisi 


\begin{tabular}{|l|l|l|l|l|l|l|}
\hline $1 / \mathrm{k}$ & Rakkolee faayinaansii & Baay’ee guddaa (1) & guddaa (2) & gidigaleessa (3) & Xiqqaa (4) & $\begin{array}{l}\text { Dhiibbaa hin qabu } \\
(5)\end{array}$ \\
\hline 1 & Hanqina gabaasa herregaa fayyadamu & & & & & \\
\hline 2 & $\begin{array}{l}\text { Karooraan ala faayidaa dhunfaaf maalaqa } \\
\text { baasu }\end{array}$ & & & & & \\
\hline 3 & $\begin{array}{l}\text { Hanqina bulchiinsa qarshii hojii } \\
\text { adeemsistu }\end{array}$ & & & & & \\
\hline 4 & Hanqina faayinaansii & & & & & \\
\hline
\end{tabular}

20. Daldalakeef heeyyama ni qabdaa?
a. Eeyyeen
b. Lakkii

21. Debiin kee lakk 20 lakkii dha yoo ta'ee sababni isaa maalii?
a. Heeyyema baasuun gatii guddaa waan gaafatuuf
c. Birokirasii waan baay'atuuf
b. Hubbanno dhabuun
d. Kan biraa

22. Adeemsi heeyyema hojii baafachuu baroota darban keessatti fooyya'iinsa qabaa?

a. Eeyyeen b. lakki

23. Lafa/mana amma keessatti dalagaa jirtu haala kamiin argattee?
a. Bituun
d. Nama dhuunfaarraa kireefahuun
b. Liiziidhaan
e. Namoota mootummaan laateef irraa liqeefachuun
c. Mootummaatu naaf laate
f. Kan biraa (ibsi)

24. Bakki itti dalagaa jirtuu bakka hojiichaaf hawwataa dha?
a. Eeyyeen
b. lakki

25. Bal'inni bakka itti dalagaa jirtuu hojiikeef ga'aa dha?
a. Eeyyeen
b. lakii

26. Baankii fi IMX irraa liqeefachuuf rakkoolle kamtu simudataa?

\begin{tabular}{|l|l|l|l|l|l|l|}
\hline \multirow{2}{*}{$\begin{array}{l}\text { Lajjira } \\
\text { Liqeessu }\end{array}$} & Problems faced & $\begin{array}{l}\text { Collateral } \\
\text { /qabsiisa gaafachu } \\
(2)\end{array}$ & $\begin{array}{l}\text { Bureaucracy } \\
\text { /birookiraasii } \\
(3)\end{array}$ & $\begin{array}{l}\text { Dhalli } \\
\text { guddaa ta'uu } \\
(4)\end{array}$ & $\begin{array}{l}\text { Hubannaa } \\
\text { dhabu } \\
(5)\end{array}$ \\
\hline Baankii & & & & & $\begin{array}{l}\text { Hammi } \\
\text { liqii } \\
\text { xiqaachu } \\
(6)\end{array}$ & $\begin{array}{l}\text { kanbiraa } \\
\text { IMX }\end{array}$ \\
\hline
\end{tabular}

27. Dorgommiin daldala kee mudataa jiru hangamii?
a. baay'ee guddaa
b. Guddaa
c. giddu galeessa
d. xiqqaa
e. baay'ee xiqqaa

28. Dorgomtonni kee guddaan warra kami?
a. IMX birro
b. inteerprizoota gurguddaafi giddu galeessaa
c. warren alaa galchanii fi gara alaa eeygan

29. Argamaa fi qulqullina bu'uuralee armaan gadii haala kamiin madaaltaa?

\begin{tabular}{|c|c|c|c|c|c|c|}
\hline \multirow[t]{2}{*}{$1 / \mathrm{k}$} & \multirow[t]{2}{*}{ Bu'uura misoomaa } & \multicolumn{5}{|l|}{ Qulqulina } \\
\hline & & $\begin{array}{l}\text { Baay'ee guddaa } \\
\text { (1) }\end{array}$ & $\begin{array}{l}\text { Guddaa } \\
\text { (2) }\end{array}$ & $\begin{array}{l}\text { Gidugaleessa } \\
\text { (3) }\end{array}$ & Xiqqaa (4) & $\begin{array}{l}\text { Baay'ee } \\
\text { xiqaa(5) }\end{array}$ \\
\hline 1 & Ibsaa & & & & & \\
\hline 2 & Bishaan & & & & & \\
\hline 3 & Bilbila & & & & & \\
\hline 4 & Transpoortii & & & & & \\
\hline
\end{tabular}

30. Karoora hojii/business plan/ mana hojii keetiif ni qabdaa?
a. Eeyyeen
b. lakki

31. Kanneen armaan gaditti ibsaman hangam bu'a qabeessummaa hojii kee irratti dhibbaa qabu?

\begin{tabular}{|l|l|l|l|l|l|l|}
\hline S/N & Rakkoolee gabayaa & Very high (1) & High (2) & Medium (3) & Low (4) & No effect (5) \\
\hline 1 & Hanqina gatii hawwataa murteessu & & & & & \\
\hline 2 & Hanqina bakka hawwataa & & & & & \\
\hline 3 & Baay'ina fedhii tilmaamu & & & & \\
\hline 4 & $\begin{array}{l}\text { Hanqina akkakku garaa garaa qabachuu fi } \\
\text { foyyeessu dadhabu }\end{array}$ & & & & & \\
\hline 5 & $\begin{array}{l}\text { Hanqina maamila qabachu fi hariiroo gaari } \\
\text { umuu }\end{array}$ & & & & \\
\hline 6 & Dandeetti nagadaa & & & & & \\
\hline 7 & Dandeetti beeksisuu & & & & \\
\hline 8 & Tamsaasa gaarii fi networki qabaachu & & & & & \\
\hline
\end{tabular}

32. Haalli gibiraa amanamaa dha/fair/ jettee amantaa?
a. Eeyyeen
b. lakki

33. Bu'aa dalagaa kee akkamitti ilaaltaa
a. Hir'achaa
b. guddachaa adeema

34. Bu'aa dalagaa kee maliif fayyadamtaa? 

a. Babal'ina mana dalagaa tiif
c. Baasii jireenya manaa tiif
b. Qusannaaf
d. Kan biraaf

35. Kanneen armaan gaditti ibsaman hangam bu'a qabeessummaa hojii kee irratti dhibbaa qabu?

\begin{tabular}{|l|l|l|l|l|l|l|}
\hline $1 / \mathrm{k}$ & Rakkoolee gabayaa & Very high (1) & High (2) & Medium (3) & Low (4) & No effect (5) \\
\hline 1 & Hojiirra olmaa qajeelfamaa & & & & & \\
\hline 2 & Hanqina bakka hojii & & & & & \\
\hline 3 & Hanqina liqii & & & & & \\
\hline 4 & Guddina gibiraa & & & & & \\
\hline 6 & Seera gibiraa sirriiit beeku & & & \\
Qulqullina tajajila waajjiraalee \\
7 & Shoragaraa of raw materials & & & & & \\
\hline 9 & Hanqina bulchiinsaa & & & & & \\
\hline
\end{tabular}

36. Muxxannoon dalagaa kana irraa argatte hojii biraa jalqabuuf ga'aa dha?

a. Eeyyeen b. lakkii

Yeroo keessan Raga kana gutuuf waan laataniif galatoomaa! 